\title{
USE OF PLASMA TECHNOLOGIES FOR THE PROTECTION OF RADIOELECTRONIC MEANS FROM THE INFLUENCE OF ELECTROMAGNETIC RADIATION
}

\author{
A. SOTNIKOV ${ }^{1}$, M. YASECHKO ${ }^{2}$
}

\author{
${ }^{1}$ Leading Senior Research Assotiate of Scientific Center of Air Forces of Ivan Kozhedub Kharkiv National Air Force University \\ Kharkiv, UKRAINE \\ ${ }^{2}$ Senior Lecturer of the Department of armament radio troops Ivan Kozhedub Kharkiv National Air Force University Kharkiv, \\ UKRAINE \\ *email:maxnik8888@gmail.com
}

\begin{abstract}
The urgency of the improvement of methods and means of protection of radio electronic means (REM) due to the development and application of high-power electromagnetic radiation (EMR) generators with ultrashort pulses duration (UPD) is substantiated. It is pointed out that it is possible to solve the problem of REM protection by the complex application of plasma technologies using gaseous and modified solid-state media.

By analyzing the known achievements in the field of developing effective methods and creating protection facilities for REM, a number of unresolved problems in the field of creation of plasma protection technologies have been determined.

The technique of solving the formulated problems is presented and the main relations are obtained to determine the expediency of using the proposed technology in the interests of the REM integrated protection from the powerful EMR UPD.

A relation is made for the breakdown criterion in a gaseous plasma medium that relates the value of the breakdown field to the concentration of charged particles determined by the ionization source. The structure of a solid-state plasma medium is described, which can be used as a protective shield. The order of finding the REM screening coefficient is shown, based on the determination of the distribution function of charged particles for finding the main macroscopic properties of plasma by solving the kinetic equation of the Lenard-Balescu equation. A relation is given for the damping coefficient of an electromagnetic wave in solidstate plasma. Numerical estimates are presented in the form of graphs showing the possibility of using plasma technology to protect the REM from a powerful EMR through possible channels of penetration. The discussion of the obtained results is presented and it is indicated on the possibility and prospects of using the proposed technology for REM protection, especially with limitations on the weight dimensions of protection devices.
\end{abstract}

Keywords: radio electronic means; electromagnetic radiation; ultrashort pulse duration; plasma protection technologies; gaseous and solid-state plasma media; hexaferrite inclusions.

\section{ИСПОЛЬЗОВАНИЕ ПЛАЗМЕННЫХ ТЕХНОЛОГИЙ ДЛЯ ЗАЩИТЫ РАДИОЭЛЕКТРОННЫХ СРЕДСТВ ОТ ВОЗДЕЙСТВИЯ ЭЛЕКТРОМАГНИТНЫХ ИЗЛУЧЕНИЙ}

\section{А. М. СОТНИКОВ ${ }^{1}$, М. Н. ЯСЕЧКО}

\footnotetext{
${ }^{I}$ Ведущий научный сотрудник научного центра Воздушных Сил Харьковского национального университета Воздушных Сил им. Ивана Кожедуба Харьков, УКРАИНА

2 Стариий преподователь кафедри вооружения радиотехнических войск Харьковского начионального университета Воздушных Сил им. Ивана Кожедуба Харьков, УКРАИНА
}

\begin{abstract}
АННОТАЦИЯ Обоснована актуальность совершенствования методов и средств защиты радиоэлектронных средств (РЭС), обусловленная разработкой и применением генераторов мощннгго электромагнитного излучения (ЭМИ) $c$ ультракороткой длительностью импульсов (УКДИ). Указано на возможность решения проблемы защиты РЭС на основе комплексного применения плазменных технологий с использованием газообразных и модифичированных твердотельных сред.

Путем анализа известных достижений в области разработки эффективных методов и создания средств защиты РЭС определен круг не решенных задач в области создания плазменных технологий защиты.

Указаны возможные пути решения сформулированных задач. Приведены соотношения для предварительной оценки и определения иелесообразности использования предлагаемой технологии в интересах комплексной защиты РЭС от мощного ЭМИ УКДИ. В частности, приведено соотношение для критерия пробоя в газообразной плазменной среде, связывающее величину пробойного поля с кониентрачией заряженных частии газообразной среды, определяемой источником ионизачии. Приведена простейшая структура твердотельной плазменной среды, которая может стать
\end{abstract}


базовой для разработки защитного экрана. Указан порядок нахождения коэффициента экранирования РЭС, основанньй на определении функции распределения заряженных частии для нахождения основных макроскопических свойств плазмы путем решении кинетического уравнения Ленарда-Балеску. Приведено соотношение для коэффициента затухания электромагнитной волны в твердотельной плазме. Приведены численные оценки, показываюшие возможность применения плазменной технологии для защуиты РЭС от мощуного ЭМИ по возможным каналам проникновения. Представлено обсуждение полученных результатов и указано на возможность и перспективность применения предлагаемой технологии для зашуиты РЭС, особенно при ограничениях на весогабаритные характеристики устройств защчтты.

Ключевые слова: радиоэлектронные средства; электромагнитное излучение; ультракороткая длительность импульса; плазменные технологии защиты; газообразные и твердотельные плазменные среды; гексаферритовые включения.

\section{Introduction}

Development, creation and use of generators with a radiation power of the order of and more than $1 \mathrm{GW}$ with pulse duration of $10^{-9}$ to $10^{-15}$ seconds necessitates the further development of methods and devices for the protection of radio electronic means. This is due to the possibility of both accidental and deliberate (as a result of terrorist acts) use of such generators, which can lead to the REM disruption at considerable distances. At the same time, the threat of REM serviceability disruption is usually created when electromagnetic radiation (EMR) interacts with antennas, communication lines, conductors and radioelements of equipment. This interaction leads to the transformation of the electromagnetic field into voltages and currents.

The most vulnerable to the EMR influence are the REM elements directly connected to the antenna output, to the cables and conductors. In addition to these elements, the cables themselves are exposed to impulse voltages, which in certain cases can damage their insulation and cause a short circuit between its cores and the sheath. The most dangerous in terms of its impact on radio electronic equipment (REE) is a powerful EMR of the ultrashort pulse duration (UPD) [1].

Proceeding from this, the problem of ensuring the durability and reliability of modern REM to the impact of powerful EMR of ultrashort pulse duration acquires a pronounced systemic character.

REE features, as a protection object, determine the requirements for the applied protective devices, which must:

- have high speed;

- not influence the characteristics of the protected radio facilities;

- have stability of characteristics in a wide range of temperatures under the action of damaging EMR factors;

- have ability to quickly restore its electrical strength in conditions of multiple exposure to EMR;

- have overall dimensions and weight smaller than the overall dimensions and mass of the protected equipment.

An analysis of the capabilities of the methods and means of protection developed to date has shown that they do not fully meet the requirements for the REM protection.

The issues of development of methods and means for REM protection from the impact of a powerful EMR have been devoted to a significant number of publications. So in [2] for the first time the radioisotope- plasma technology of creation of absorbing materials for REM protection from EMR is proposed. However, the results of the studies do not take into account the possibility and necessity of controlling the electrophysical properties of the material by changing its magnetic permeability. In [3], the results of creating a number of multilayer materials that ensure the EMR absorptio in the frequency range $8-80 \mathrm{GHz}$ are more than $10 \mathrm{~dB}$. In [4], an approach is proposed to evaluate the effect of structural inhomogeneities of an electromagnetic shield on its protective properties. In [5], studies of composite materials based on hexaferrite and barium aluminates are carried out. The possibility of effective protection of biological and technical objects from EMR in the frequency range $70-90 \mathrm{GHz}$ is shown. In [6], the results of the investigation of the interaction of EMP with matter are presented. In [7], the frequency dependences of the dielectric and magnetic permeabilities of composite radio materials, which are a mixture of nano-sized powders of ferroelectrics and ferrites, are given. In [8], the possibility of changing the electromagnetic characteristics of composite radio materials by adding a ferroelectric to a ferromagnetic material is shown. In [9], broadband absorbing coatings are proposed that provide for the absorption of EMR more than $10 \mathrm{~dB}$ in the frequency range $8-80 \mathrm{GHz}$. In [10], the structure of broadband coatings using a semiconductor matrix with radioisotope inclusions is considered. In [11], the generator of switching aperiodic impulses of superhigh voltage for tests of electric strength of isolation of technical objects is considered. In [12], the issue increase the accuracy of calculating the parameters to be standardized earthing devices of operating electrical installations.

Thus, despite a wide range of ongoing research in the development of effective methods and the creation of means for REM protection from the impact of a powerful EMR, there is no protection technology. In turn, the protection technology should provide a unified methodological position for solving the problem of reducing the level of electromagnetic field intensity affecting the REM. The solution of the existing problem is proposed on the basis of the complex application of plasma protection technologies using gaseous and modified solid-state media.

The aim of the work: assessment of the possibility of using plasma media for complex REM protection from the impact of a powerful pulsed EMR.

To achieve this aim, the following research objectives are solved:

- assessment of the possibility of using gaseous 
plasma media to REM protection by the main reception channels and cable penetration channels;

- evaluation of the possibility of using solid-state plasma media with the use of hexaferrite inclusions in the dielectric matrix as protective shields of the REM cases.

\section{The aim of the work}

The aim of the work: assessment of the possibility of using plasma media for complex REM protection from the impact of a powerful pulsed EMR.

To achieve this aim, the following research objectives are solved:

- assessment of the possibility of using gaseous plasma media to REM protection by the main reception channels and cable penetration channels;

- evaluation of the possibility of using solid-state plasma media with the use of hexaferrite inclusions in the dielectric matrix as protective shields of the REM cases.

\section{Main part}

The basic idea of using a gaseous plasma medium for the REM protection is use of ionization source and to create conditions for the appearance of a breakdown in an ionized medium. As a result, the EMR does not penetrate into the subsequent cascades or into the enclosure. Under the EMR influence, it closes in an ionized environment with high conductivity and prevents further penetration. After the termination of the EMR action, the conductivity of the gaseous plasma is sharply reduced, and the REM continues to operate in the normal mode.

The solution of the problem of assessing the possibility of using gaseous plasma media to REM protection by the main reception channels and cable penetration channels is based on the Krook model

$$
\frac{\partial f_{a}}{\partial t}+V \frac{\partial f_{a}}{\partial x}+\frac{q_{a}}{m_{a}}\left(E+\frac{V x B}{C}\right) \frac{\partial f_{a}}{\partial V}=\frac{f_{a}(x, V, t)-f_{a_{0}}}{\tau_{a}},
$$

where $\mathrm{q}_{\mathrm{a}}-$ the particle charge; $\mathrm{m}_{\mathrm{a}}-$ the particle mass.

The Crook model allows to determine:

- distribution function $f_{a}$, necessary for estimating the main macroscopic layers of the ionized medium;

- establish a connection with the intensity of the electromagnetic field;

- determine the conditions of ignition and the occurrence of breakdown.

The value of the breakdown field $\mathrm{E}_{\mathrm{b}}$ is taken to be the value at which the maximum plasma concentration in the perturbed region is equal to the critical value $\mathrm{n}_{\mathrm{cr}}$, and corresponds to the frequency at which the spectrum has a maximum:

$$
4 \pi n_{c r} e^{2} / m_{e}=\left(2 \pi / \tau_{p}\right)^{2}
$$

The breakdown criterion has the form:

$$
\ln \frac{n_{c r}}{n_{e_{0}}}=\frac{a \tau_{p}}{2 \pi} \int_{0}^{\theta_{m}} \varepsilon(\theta) d \theta+\left(b+v_{a}\right) \tau_{m}
$$

where $\tau_{m}$ - the time at which $n_{e}=n_{c r}, \theta_{m}=\tau_{m} 2 \pi / \tau_{p}$ Investigation of the use of solid-state plasma as protective shields is based on thr material with the following structur

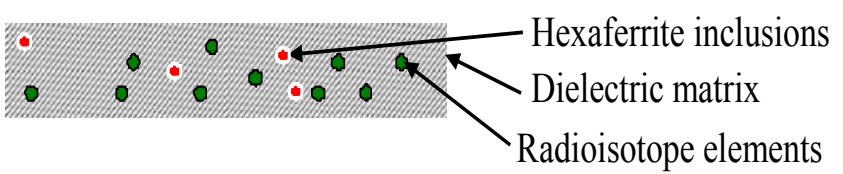

\section{Fig. 1- Structure of the protective material}

The dielectric matrix contains both hexaferrite inclusions and radioisotope elements. The first are necessary for controlling the magnetic permeability of the shield, the latter for creating a non-equilibrium state of the electronic subsystem with the aim of increasing the dielectric losses. The state of a solid-state ionized medium is described by the Lenard-Balescu kinetic equation. In the case of a gaseous plasma medium, this equation makes it possible to determine the distribution function and the finding of frequency-dependent dielectric, magnetic permeabilities. This, in turn, makes it possible to determine the EMR damping rate $\gamma / \omega$ through the parameters of the medium

$$
\frac{\gamma}{\omega}=0.5 \sqrt{\frac{\pi}{2}} \frac{1}{\left(k / k_{d q}\right)^{3}} \exp \left(-\frac{3}{4}\left(k_{d q} / k\right)^{2}\right)
$$

where $\mathrm{k}$ - the wave vector; $k_{d q}-$ the Debye wave vector.

\section{Results}

1. The case of a gaseous plasma medium. The dependence of the logarithm of the ratio of electron densities to the pulse amplitude for different pulse durations, obtained using (1), is shown in Fig. 2

It is established that the breakdown intensity of the electric field depends on the initial concentration of electrons in the discharge volume and the EMR duration. When the ratio of the critical concentration to the initial concentration is changed only by a factor of 5 and the air pressure is $750 \mathrm{~mm} \mathrm{Hg}$, the breakdown strength of the field decreases from $30 \mathrm{kV} / \mathrm{m}$ to $20 \mathrm{kV} / \mathrm{m}$. With an increase in the pulse duration by an order of magnitude, the breakdown field strength is reduced by a factor of $5 \mathrm{lg}$ $n_{c r} / n_{e 0}=20$. As the EMR duration is increased by a factor of 10 , the breakdown strength of the electric field decreases by a factor of 3 . 


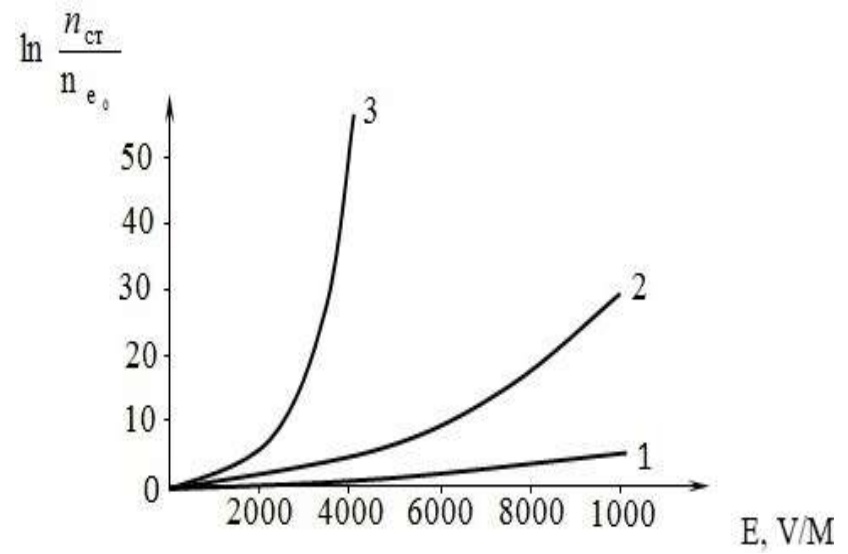

Fig. 2 -Dependence of the logarithm of the ratio of the electron density to the electric field strength for times: 1 - 0.01; 2 - 0.1; 3 - 1 in fractions of the pulse duration $\tau_{p}=3 n s$

2. The case of a solid-state plasma medium. The dependence of the EMR damping $\gamma / \omega$ on the nonequilibrium parameter is shown in Fig. 3.

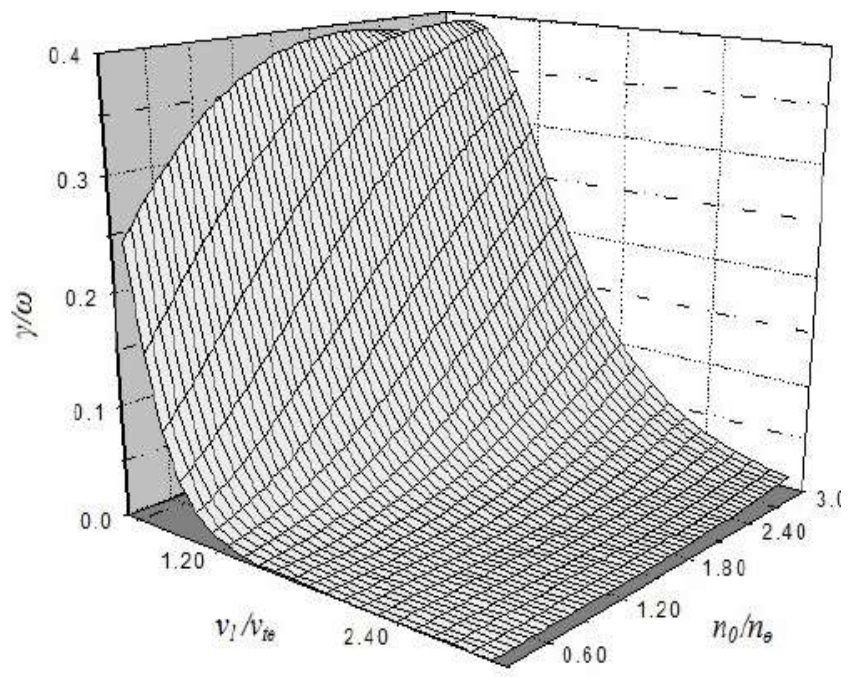

Fig. 3 - Dependence of EMR damping on the nonequilibrium parameter of solid-state plasma

In accordance with (3) for the intensity of the radioisotope source of $70 \mu \mathrm{Cu} / \mathrm{cm}^{2}$, due to the nonequilibrium properties of solid-state plasma, the EMR damping coefficient can reach values of the order of 70 dB.

\section{Conclusions}

1. The performed theoretical evaluations testify to the principle possibility of using the proposed technologies for creation of means for REM protection from the EMR influence. The choice of the required initial electron concentration in the gaseous plasma leads to a decrease in the breakdown field strength.
Consequently, when creating the necessary initial electron concentration inside the waveguide or between the walls of the case and the cable braiding, a real possibility of REM protection from the impact of powerful EMR appears.

2. The use of a solid-state plasma medium as a shielding material by selecting the intensity of the radioisotope source, as well as the number of layers of the dielectric matrix, allows controlling the absorbing properties of the material. The promising nature of the proposed technology lies in the possibility of its integrated use to protect against possible penetration channels, with limitations on the weight dimensions of protection devices.

\section{Bibliography}

1. Балюк, Н. В. Мощный электромагнитный импульс: воздействие на электронные средства и методы защиты / Н. В. Балюк, Л. Н. Кечиев, П. В. Степанов - М.: ООО «Группа ИТД», 2007. — 478 c.

2. Vorobiov, O. Development of radioisotopicplasmatechnology for the protection of radio electronic means from powerful electromagnetic radiation [Text] / O. Vorobiov, V. Savchenko, A. Sotnikov, V. Tarshin, T. Kurtseitov // Eastern-European Journal of Enterprise Technologies. - 2017. - Vol. 1, № 5 (85). - P. 16-22. - doi: 10.15587/1729-4061.2017.91642.

3. Skoblikov, O. Shielding Properties of Conductive Shells Exposed to Electromagnetic Impulse of Lightning [Electronic resource] / O. Skoblikov, V. Knyazyev // International Conference on Lightning Protection (ICLP'2012). - Vienna. - 2012. - P. 1-8.

4. Махно, С. Н. Взаимодействие электромагнитного излучения с веществом: некоторые направления развития исследований и перспективы практического использования [Текст] / С. Н. Махно, П. П. Горбик // Поверхность. - 2010. - Вып. 2(17). — С. $14-18$.

5. Barsova, Z. V. Chemistry and technology of magnetite and barium-containing composite materials on its basis [Text] / A. Tajirov, I. V. Cwhanovskaya, Z. V. Barsova, N. G. Iluoykha // European Science and Technology: materials of the II international research and practice conference, - 2012. - Vol. II, May 9th10th, 2012. - P. 80-87.

6. Fazaeli, R. Microwave Absorption Properties of Low Density Polyethelene-Cobalt Ferrite Nanocomposite [Text] / R. Fazaeli, R. Eslami-Farsani, H. Targhagh // International Journal of Chemical, Molecular, Nuclear, Materials and Metallurgical Engineering. 2015. - Vol. 9, No. 12. - P. 1450-1453.

7. Liu, T. The hierarchical architecture effect on the microwave absorption properties of cobalt composites [Text] / T. Liu, P. H. Zhou, J. L. Xie, L. J. Deng // J. Appl. Phys. - 2011. — Vol. 110. - P. 1-4. - doi: $10.1063 / 1.3622144$.

8. Петров, В. Исследование радиопоглощающих свойств материалов на основе наноструктур [Текст] / В. Петров, Г. Николайчук, С. Яковлев, Л. Луцев // Компоненты и технологии. - 2008. - № 12. C. $141-146$. 
9. Mazov, I. N. Electrophysical and electromagnetic properties of pure MWNTs and MWNT/PMMA composite materials depending on their structure [Text] / I. N. Mazov, V. L. Kuznetsov, S. I. Moseenkov end ot. // Fullerenes, nanotubes and carbon nanostructures. - 2010. - Vol. 18. - P. 505-515.

10. Сотніков, О. М. Розробка структури матеріалу захисних екранів радіоелектронних засобів озброєння i військової техніки від впливу потужних електромагнітних випромінювань ультракороткої тривалості імпульсу / О.М. Сотніков, А.В. Крижний, О.М. Воробйов // Труди Університету. К.: Національний університет оборони Украйни. 2013. - № 6 (120). - C. 187-191.

11. Колиушко, Г. М. К вопросу повышения точности расчета нормируемых параметров заземляющих устройств действующих электроустановок / Г. М. Колиушко, Д. Г. Колиушко, С. С. Руденко // Електротехніка $і$ електромеханіка. - 2014. - 4. C. 65-70. - doi: 10.20998/2074-272x.2014.4.13.

12. Баранов, М. И. Генератор коммутационных апериодических импульсов сверхвысокого напряжения для испытаний электрической прочности изоляции технических объектов / М. И. Баранов, Г. М. Колиушко, В. И. Кравченко // Приборы $и$ техника эксперимента. - 2013. - No6. - С. 30-35. doi: $10.1134 / \mathrm{s} 0020441213050126$.

\section{Bibliography (transliterated)}

1. Balyuk, N. V., Kechy`ev, L. N., Stepanov, P. V. Moschnyiy elektromagnitnyiy impuls: vozdeystvie na elektronnyie sredstva i metodyi zaschityi [Powerful electromagnetic impulse: affecting electronicfacilities and methods of defence]. Moscow, Russia: Gruppa ITD, 2007, 478.

2. Vorobiov, O., Savchenko, V., Sotnikov, A., Tarshin, V., Kurtseitov, T. Development of radioisotopicplasmatechnology for the protection of radio electronic means from powerful electromagnetic radiation, 2017, 1, № 5 (85), 16-22. - doi:10.15587/1729-4061.2017.91642.

3. Skoblikov, O., Knyazyev, V. Properties of Conductive Shells Exposed to Electromagnetic Impulse of Lightning. International Conference on Lightning Protection (ICLP'2012). Vienna (Austrian), 2012, 1-8.

4. Mahno, S. N., Gorbikm P. P. Vzaimodeystvie elektromagnitnogo izlucheniya s veschestvom: nekotoryie napravleniya razvitiya issledovaniy i perspektivyi prakticheskogo ispolzovaniya [Co-operating of electromagnetic radiation with a substance: some directions of development of researches and prospectof the practical use]. Poverhnost, 2010, 2(17), 14-18.

5. Tajirov, A., Cwhanovskaya, I. V., Barsova, Z. V., Iluoykha, N. G. Chemistry and technology of magnetite and barium-containing composite materials on its basis. European Science and Technology: materials of the II international research and practice conference. Wiesbaden (Germany), 2012, 80-87.

6. Fazaeli, R., Eslami-Farsani, R., Targhagh, H. Microwave Absorption Properties of Low Density Polyethelene-Cobalt Ferrite Nanocomposite. International Journal of Chemical, Molecular, Nuclear, Materials and Metallurgical Engineering, 2015, 9(12), 1450-1453.

7. Liu, T., Zhou, P. H., Xie, J. L., Deng, L. J. The hierarchical architecture effect on the microwave absorption properties of cobalt composites. J. Appl. Phys., 2011, 110, 1-4. - doi: 10.1063/1.3622144.

8. Petrov, V., Nikolaychuk, G., Yakovlev, S., Lutsev, L. Issledovanie radiopogloschayuschih svoystv materialov na osnove nanostruktur [Research of radiopogloschayuschih properties of materials on the basis of nanostructures]. Komponentyi $i$ tehnologii, 2008, 141-146.

9. Mazov, I. N., Kuznetsov, V. L., Moseenkov, S. I. Electrophysical and electromagnetic properties of pure MWNTs and MWNT/PMMA composite materials depending on their structure. Fullerenes, nanotubes and carbon nanostructures, 2010, 18, 505-515.

10. SotnIkov, O. M., Krizhniy, A. V., Vorobyov, O. M. Rozrobka strukturi materialu zahisnih ekraniv radioelektronnih zasobiv ozbroennya i viyskovoyi tehniki vid vplivu potuzhnih elektromagnitnih viprominyuvan ultrakorotkoyi trivalosti impulsu [Development of structure of material of protective screens ofradio electronic facilities of armament and military techniqueis from influence of powerful electromagnetic radiations ofultra-short pulsewidth]. Trudu Universitetu, 2013, 6(120), 187-191.

11. Baranov, M. I., Koliushko, G. M., Kravchenko, V. I. A switching aperiodic superhigh-voltage pulse generator for testing the electric strength of insulation of technical objects. Instruments and Experimental Technique, 2013, 56, no.6, 653-658. $\quad-$ doi: $10.1134 / \mathrm{s} 0020441213050126$

12. Koliushko, G. M., Koliushko, D. G., Rudenko, S. S. On the problem of increasing computation accuracy for rated parameters of active electrical installation ground grids. Electrical engineering \& electromechanics, 2014, 4, 65-70. - doi: 10.20998/2074-272x.2014.4.13

\section{Сведения об авторах (About authors)}

Alexander Sotnikov - doctor of technical sciences, professor, Kharkiv National University of Air Forces named after. Ivan Kozheduba, Leading Researcher of the Air Force Research Center; Kharkov, Ukraine; e-mail: alexsot@ukr.net.

Сотников Александр Михайлович - доктор технических наук, профессор, Харьковский национальный университет Воздушных Сил им. Ивана Кожедуба, ведущий научный сотрудник научного центра Воздушных Сил; г. Харьков, Украина; e-mail: alexsot@ukr.net.

Maksim Yasechko - Candidate of Technical Sciences (Ph. D.), Senior Lecturer of the Department of armament radio troops, Kharkiv National Air Force University, Kharkiv, Ukraine; e-mail: maxnik8888@gmail.com.

Ясечко Максим Николаевич - кандидат технических наук, Харьковский национальный университет Воздушных Сил им. Ивана Кожедуба, старший преподователь кафедри вооружения радиотехнических войск; г. Харьков, Украина; е-таil: maxnik8888@gmail.com. 
Please cite this article as:

Sotnikov, A., Yasechko, N. Use of plasma technologies for the protection of radioelectronic means from the influence of electromagnetic radiation. Bulletin of NTU "KhPI". Series: New solutions in modern technologies. - Kharkiv: NTU "KhPI", 2017,53 (1274), 182-187, doi:10.20998/2413-4295.2017.53.25.

Пожалуйста, ссылайтесь на эту статью следующим образом:

Сотников, А. М. Использование плазменных технологий для защиты радиоэлектронных средств от воздействия электромагнитных излучений / А. М. Сотников, М. Н. Ясечко // Вестник НТУ «ХПИ», Серия: Новые решения 6 современных технологиях. - Харьков: НТУ «ХПИ». - 2017. - № 53 (1274). - С.182-187. - doi:10.20998/2413-4295.2017.53.25.

Будь ласка, посилайтесь на ичю статтю наступним чином:

Сотніков, О. М. Використання плазмових технологій для захисту радіоелектронних засобів від впливу електромагнітних випромінювань / О. М. Сотніков, М. М. Ясечко // Вісник НТУ «ХПI», Серія: Нові рімення в сучасних технологіях. - Харків: НТУ «ХПІ». - 2017. - № 53 (1274). - С. 182-187. - doi:10.20998/2413-4295.2017.53.25.

АНОТАЦІЯ Обгрунтовано актуальність вдосконалення методів $і$ засобів захисту радіоелектронних засобів (РЕЗ), обумовлена розробкою $i$ застосуванням генераторів потужного електромагнітного випромінювання (ЕМВ) 3 ультракороткою тривалістю імпульсів (УКДІ). Зазначено на можливість вирішення проблеми захисту РЕЗ на основі комплексного застосування плазмових технологій з використанням газоподібних $i$ модифікованих твердотільних середовищ.

Шляхом аналізу відомих досягнень в області розробки ефективних методів і створення засобів захисту РЕз визначено коло невирішених завдань в області створення плазмових технологій захисту.

Ключові слова: радіоелектронні засоби; електромагнітне випромінювання; ультракоротка тривалість імпульсу; плазмові технології захисту; газоподібні і твердотільні плазмові середовища; гексаферрітове включення. 